\title{
Wnt Target Proteins Up-Regulated in Tear Film of Corneal Ulcer Mediates YAP1 Activation and Corneal Pathology in Dogs Suffering from Keratoconjunctivitis Sicca
}

\author{
Sasikala R. ${ }^{1}$, Aswathy Gopinathan ${ }^{1}$, Kiranjeet Singh ${ }^{1}$, Swapana CR ${ }^{1}$, Akshay Kumar ${ }^{1}$, \\ Sowbharenya Chelladuraai ${ }^{1}$, Monalisa Sahoo ${ }^{2}$ and Ravi Kant Agrawal ${ }^{3}$ \\ ${ }^{1}$ Division of Surgery, ICAR-IVRI, Izatnagar, Barielly (U.P.) Uttar Pradesh, INDIA \\ ${ }^{2}$ Division of Pathology, ICAR-IVRI, Izatnagar, Barielly (U.P.) Uttar Pradesh, INDIA \\ ${ }^{3}$ Division of Livestock Products Technology, ICAR-IVRI, Izatnagar, Barielly (U.P.) Uttar Pradesh, INDIA
}

"Corresponding author: A Gopinathan; E-mail: aswathykiran77@gmail.com

\begin{abstract}
The study was performed to identify Wnt and YAP1 target proteins and regulators in the tear fluid and the role of Timolol $(0.5 \%$ $\mathrm{w} / \mathrm{v}$ ) in corneal wound healing by mediating YAP1 activation in dogs suffering from corneal ulcer due to Keratoconjunctivitis sicca (KCS). Complete clinical examination, the staging of KCS cases, and tear fluid collection were done. Protein identification from tryptic peptides of tear fluid of KCS cases was done through Matrix-assisted laser desorption/ ionization-time of flight mass spectrometry (MALDI-TOF/ MS). Dynamics of YAP1 and its downstream targets CTGF and E-Cadherin in Tear fluid through immuno-blotting and in-situ detection through Immuno-histochemistry (IHC) was done. The role of Timolol $(0.5 \% \mathrm{w} / \mathrm{v})$ in the corneal healing through activation of YAP and CTGF was studied. Wnt target proteins like Frizzled-6 (FZD6), Catenin beta1(CTNNB1), G1/S-specific cyclin-D1(CCND1), Vascular cell adhesion protein-1 (VCAM-1), and Matrix metalloproteinase-9 (MMP-9) were found significantly up-regulated $(\mathrm{p}<0.05)$ in corneal ulcer $(\mathrm{KCS})$. YAP1 regulators Tyrosine-protein kinase Yes (YES1) was found significantly up-regulated $(\mathrm{p}<0.05)$ whereas Leukemia inhibitory factor receptor (LIFR), Angiopoietin-1 (Ang-1) and Rho GTPase-activating protein 7 (DLC1) ( $\mathrm{p}<0.001)$, Tight junction protein ZO-3 (TJP3), and Cadherin-1 (CDH1) $(p<0.05)$ were significantly down-regulated in corneal ulcer compared to normal tear. Increased expression of YAP1 and CTGF was observed in the tear film and corneal tissues of corneal ulcer cases. Up-regulation of the Wnt target proteins and YAP1 activation occurred in corneal ulcer due to KCS and orchestrated characteristic corneal pathology. Timolol enhanced cell proliferation and thus was helpful in corneal healing but augmented KCS pathology in corneal tissue.
\end{abstract}

\section{HIGHLIGHTS}

0 Up-regulation of the Wnt target proteins and activation of YAPloccurred in corneal ulcer due to KCS and orchestrated characteristic corneal pathology.

( Timolol enhanced cell proliferation and was helpful in corneal healing but augmented KCS pathology in corneal tissue.

Keywords: Wnt Target Proteins, Tear Film, Corneal Ulcer, KCS, dog

The corneal ulcer is a common complication of Keratoconjunctivitis sicca (KCS) in dogs. KCS is an immune-mediated disease targeting lacrimal glands and the ocular surface of the cornea and conjunctiva (Williams and Tighe, 2018). Corneal surface stress, associated with lagophthalmos and osmotic stress due to evaporation of protective tear film, predisposes the brachycephalic dog breed to corneal epithelial defects (Lee and Heur, 2015). Moreover, mechanical stress due to corneal edema can

How to cite this article: Sasikala, R., Gopinathan, A., Singh, K. Swapana, C.R., Kumar, A., Chelladuraai, S., Sahoo, M. and Agrawal, R.K. (2021). Wnt target proteins up-regulated in tear film of corneal ulcer mediates YAP1 activation and corneal pathology in dogs suffering from Keratoconjunctivitis Sicca. J. Anim. Res., 11(1): 147-158. Source of Support: None; Conflict of Interest: None 
cause a break in the tear film in the central cornea and make it vulnerable to ulcers. YAP1 is a transcriptional co-activator of the Hippo signaling pathway, which regulates cell growth, cell survival, and organ size (Dupont et al., 2011). Cell-to-cell contact and cellular stress are important regulators of nuclear translocation of YAP1; it promotes cell proliferation through upstream regulators and downstream targets (Dupont et al., 2011). Wnt signaling is also a critical regulator of cell fate and proliferation; an active Wnt signaling can inhibit YAP degradation and can activate YAP nuclear translocation (Konsavage and Yochum, 2013). MALDI-TOF/MS is a versatile technique to identify protein fingerprints in tears film (Swapna et al., 2020, Webster and Oxley, 2012). Beta-adrenergic antagonists have a purported role in corneal wound healing (Reidy et al., 1994). G proteincoupled $\beta$-adrenergic receptor agonist was found effective in modulating YAP activation (Bao et al., 2011). Hence, this study was performed to identify Wnt and YAP1 target proteins and regulators in the tear fluid and the role of betaadrenoceptor antagonist Timolol $(0.5 \% \mathrm{w} / \mathrm{v})$ in corneal wound healing by mediating YAP1 activation in dogs suffering from corneal ulcer due to Keratoconjunctivitis sicca (KCS).

\section{MATERIALS AND METHODS}

\section{Animals}

Dogs presented with ocular manifestations, and a corneal epithelial defect due to KCS were selected for this study. Complete ophthalmological examination was conducted to identify KCS with an indirect ophthalmoscope (Appasamy Associates, Chennai) and a 20D indirect lens (Volk optical Inc, USA), Slit lamp Bio-microscope (Appasamy Associates, Chennai), tonometer (Schiőtz C, Riester, Germany) Goniolens (OptiTech eye care, Tarun enterprises, Allahabad). Menace response, palpebral reflex, pupillary light reflex, conjunctival hyperemia, ocular discharge, corneal ulcer, corneal vessel length, corneal vessel density, corneal pigmentation area, corneal pigmentation density (John et al., 2018; Hendrix et al., 2011; John et al., 2020), and corneal clarity (Sarangom et al., 2014; John et al., 2018) were assessed subjectively and scores were assigned. Schirmer tear testing (STT1) (Schirmer tear test ophthalmic strips, (OptiTech eye care,
Tarun enterprises, Allahabad) was carried out to assess tear production and fluorescein staining (OptiTech eye care, Tarun enterprises, Allahabad) was done in order to assess the integrity of the corneal surface. STT1 was done wherein the strips were placed on the lower fornix of each eye after folding the strip of filter paper $(35 \mathrm{~mm} \times 5 \mathrm{~mm})$ at the notch and putting the folded portion between the cornea and lower eyelid. The paper was left in position for one minute and the amount of wetting $(\mathrm{mm} / \mathrm{min})$ was measured (Sansom and Barnett, 1985; John et al., 2018; John et al., 2020; Swapna et al., 2020). STT1 values were interpreted as Normal (STT $\geq 15 \mathrm{~mm} / \mathrm{min}$ ), Mild or subclinical KCS $($ STT $=11-14 \mathrm{~mm} / \mathrm{min})$, Moderate to mild KCS (STT $=6-10 \mathrm{~mm} / \mathrm{min})$, Severe KCS $(\mathrm{STT} \leq 5$ $\mathrm{mm} / \mathrm{min}$ (Corr, 2015). For FDT, the strips were moistened with sterile normal saline and a drop was placed on the conjunctiva and allowed to spread over the ocular surface. Eyes were thoroughly washed with normal saline and were examined for epithelial loss with the blue light filter of biomicroscope. The degree of loss of epithelium was scored from 1 to 3 depending on the severity as 1 (No stain retention), 2 ( $<50 \%$ retention of stain), and $3(>50 \%$ retention of stain). Corneal ulcer/epithelial defects due to KCS were graded for severity of ulcer (Miller, 2001). Corneal ulcers of grades 1, 2, and 3 were included in the study. Corneal samples for in-situ detection of YAP1, CTGF, and E-Cadherin through immunohistochemistry (IHC) were collected from cadavers of two dogs died/ euthanized and not suffering from any ocular disease as control and also from three pugs diagnosed with KCS and extensive corneal ulcer whose owners requested extirpation of the affected eyeball. Corneal tissue was excised from the eyeball with a surgical scissor, preserved in $10 \%$ neutral-buffered formal saline at room temperature till further processing.

\section{Ethics statement}

Due permission to conduct the clinical study was obtained from Committee for the Purpose of Control and Supervision of Experiments on Animals, Ministry of environment, Forest and climate change, Government of India (No.F.25/17/2019-CPCSEA dated 25/09/2019). Written consent of the owner was taken for operative procedures as well as pre- and post-operative ocular surface epithelial cells collection. 


\section{Tear sample collection and total protein estimation}

Tear samples were collected using STT ophthalmic strips (Optitech eye care, Tarun enterprises, Allahabad) in $0.5 \mathrm{ml}$ Eppendorf tubes and were frozen at $-60^{\circ} \mathrm{C}$ until tear proteomics study. For extraction of tear fluid, $0.5 \mathrm{ml}$ Eppendorf tubes containing Schirmer strips were punctured at the bottom with a cannula and were then placed in a larger $(1.5 \mathrm{ml})$ tube and centrifuged at 4000 $\times \mathrm{g}$ for 30 minutes at $4^{\circ} \mathrm{C}$ (Argüeso et al., 2002). The centrifugal force pulled the tear fluid out of the Schirmer strip, through the central "pore" in the bottom of the smaller tube and into the outer $1.5 \mathrm{ml}$ tube (Posa et al., 2013). Total protein concentration in pooled tear of each group was measured with BCA protein estimation kit (GeNei ${ }^{\mathrm{TM}}$, Bangalore).

Identification of molecular signature of Wnt and YAP target proteins through tear film MALDI-TOF/MS and PMF

Approximately $30 \mu \mathrm{g}$ of eluted tear proteins of corneal ulcer $(n=5)$ as well as normal tear $(n=5)$ in triplicate was run along with protein molecular weight marker using SDS-PAGE. Three aliquots of at least three major bands $15 \mathrm{dDa}, 24 \mathrm{dDa}$ and $66 \mathrm{dDa}$ were cut, each fraction was trypsin digested and analysed by MALDI TOF/TOF MS to separate the tryptic peptides in each band on the basis of their mass-to-charge ratio $(\mathrm{m} / \mathrm{z})$. The excised gel slices were washed thrice in deionized water, twice in $0.1 \mathrm{M} \mathrm{NH} \mathrm{NHCO}_{3}$ and twice in $50 \%$ acetonitrile. Tear proteins were reduced by addition of $0.1 \mathrm{M}$ dithiothreitol followed by incubation overnight at $37^{\circ} \mathrm{C}$. Proteins were alkylated by adding $55 \mathrm{mM}$ iodoacetamide and incubated for $30 \mathrm{~min}$ at room temperature in the dark. Trypsin was added @ 10 ng/ $\mu$ l trypsin in $0.1 \mathrm{M} \mathrm{NH}_{4} \mathrm{HCO}_{3}$ sufficient to cover the gel pieces and samples were incubated overnight at $37^{\circ} \mathrm{C}$. The digestion was stopped by adding $10 \mu \mathrm{l}$ of glacial acetic acid, and the supernatant containing the tryptic peptides was harvested. Tryptic peptides were subjected to MALDI-TOF/MS and internally calibrated spectra were acquired on a Bruker Daltonics model Ultraflex II Spectrometer. Mass spectra generated were used for PMF search with MASCOT and MS-FIT against Swissprot 2017. 06 database with following parameters: global modification of carbamidomethyl (C); possible modification as oxidation (M), Peptide mass tolerance of
300 ppm, Fragment mass tolerance of $0.1 \mathrm{Da}$ and 1 missed cleavage (Soria et al., 2017). Proteins were identified based on MOWSE score $(>69)$, minimum matches of at least 4 peptides for individual protein detection through MS-FIT.

\section{Dynamics of YAP1 and its downstream targets CTGF and E-Cadherin in Tear fluid through immuno-blotting}

Total protein concentration in the pooled tear sample of each group was measured with BCA protein estimation kit (GeNei ${ }^{\mathrm{TM}}$, Bangalore). Equal volume of pooled tear fluid was collected and was run on $12 \%$ SDS PAGE. The resolved proteins were then transferred onto PVDF membranes using a semi dry blotting apparatus (Bio-Rad) in $1 \mathrm{X}$ transfer buffer (appendix) at a constant current of $80 \mathrm{~mA}$ for $1 \mathrm{~h}$. Unbound surface of the membranes were blocked overnight with $3 \%$ BSA at $4{ }^{\circ} \mathrm{C}$, washed with PBS-Tween $(0.05 \%) 3$ times for ten min and were treated with primary antibodies for YAP (YPA1411; Chongqing Biospes, China), CTGF (YPA1291; Chongqing Biospes, China) and E-cadherin (YPA1605; Chongqing Biospes, China). Blocked PVDF membranes were submerged in diluted primary antibody and were incubated at room temperature for $2 \mathrm{~h}$ with gentle shaking. HRP-Conjugated goat anti- Rabbit IgG antibody (BSA1013, Chongqing Biospes, China) was used as the secondary antibody. After secondary antibody treatment, the PVDF membranes were washed, incubated with the DAB substrate solution for colour development at $37^{\circ} \mathrm{C}$ until the desired intensity signal was obtained. Reaction was stopped by dipping the membrane in distilled water a few times. The membrane was subsequently scanned to identify the band intensity.

\section{In-Situ detection of YAP1, CTGF and E-Cadherin in Corneal Ulcer (KCS) through Immuno-histochemistry (IHC)}

IHC was performed to localize the YAP, CTGF and E-cadherin proteins in corneal ulcer in dogs suffering from KCS. For IHC, corneal tissue was fixed in $10 \%$ neutralbuffered formalin and processed for preparing paraffin block. Following deparaffinization, washed slides were processed for antigen retrieval. Heat-mediated antigen retrieval was done by immersing the slides in $50 \mathrm{ml}$ of $1 \mathrm{x}$ heat-mediated antigen retrieval solution ( $\mathrm{pH}$ 6.0; Abcam, USA) in a Coplin jar. After washing with TBST (1X), the 
slides were incubated for 15-30 min with $\mathrm{H}_{2} \mathrm{O}_{2}(3 \%$; in methanol) in a humidified chamber to saturate the tissue endoperoxidase activity. MF-Millipore ${ }^{\mathrm{TM}}$ (Merck) filtered goat serum $(10 \%)$ in PBS was flooded over the tissue sections and incubated in a humidified chamber for 1-2 $\mathrm{h}$ at room temperature for blocking the non-specific binding sites and to prevent the non-specific interaction of primary and secondary antibodies with various antigens. The tissue sections were flooded with the primary antibody (diluted in filtered $1 \%$ BSA in PBS) in the desired dilution and incubated overnight in a closed humidified chamber at $4^{\circ} \mathrm{C}$. After incubation, the sections were washed at least thrice with 1x TBST (5 min for each) by keeping coplin jar on gel shaker. The primary antibodies used were rabbit polyclonal anti-transcriptional co-activator YAP, CTGF and E-cadherin antibody (Chongqing Biospes Co., Ltd, China). Slides were incubated with HRP-Conjugated Goat anti- Rabbit IgG antibody for one hour at room temperature in a humidified chamber. The slides were washed and were flooded with ImmPACT ${ }^{\circledR}$ DAB solution and incubated until the desired colour intensity was developed. Counterstaining was done with freshly prepared Mayer's hematoxylin stain for few seconds (30-40 s) and followed by a gentle wash with distilled water. The DPX -mounted sections were visualized for immunoreactivity under a light microscope at desired magnification.

Clinical evaluation of $\boldsymbol{\beta}$-adrenoceptor antagonistTimolol $(0.5 \% \mathrm{w} / \mathrm{v})$ drops treatment in corneal ulcer healing in KCS affected dogs

Effect of beta-adrenergic receptor antagonist Timolol $(0.5 \% \mathrm{w} / \mathrm{v})$ in healing of corneal ulcer/epithelial defect was evaluated in KCS affected dogs, twelve animals with ulcers of grade 1, 2 and 3 were randomly having six animals in each groups A and B (Table 1). Treatment was evaluated on the basis of ophthalmological evaluation; clinical parameters evaluated were Conjunctival hyperemia, Ocular discharge, Corneal clarity, Severity of corneal ulcer, Corneal vessel length, Corneal vessel density, Corneal pigmentation, Corneal pigmentation density. STT and FDT and digital photographs were taken on the day of presentation day $0,7^{\text {th }}, 14^{\text {th }}$ and $28^{\text {th }}$ posttreatment to evaluate the effect of medical management of corneal ulcer.
Table 1: Evaluation of $\beta$ adrenoceptor antagonist- Timolol $(0.5 \%)$ drops on healing of corneal ulcer in KCS affected dogs

\begin{tabular}{llll}
\hline Group & $\begin{array}{l}\text { No. of } \\
\text { Animal }\end{array}$ & $\begin{array}{l}\text { Treatment } \\
\text { (4 Times/Day) }\end{array}$ & Follow Up \\
\hline A & 6 & Control & $\begin{array}{l}7,14,28^{\text {th }} \text { days } \\
\text { post treatment }\end{array}$ \\
B & 6 & $\begin{array}{l}\text { Timolol }(0.5 \% \text { w } / v) \text { eye } \\
\text { drops }\end{array}$ & $\begin{array}{l}7,14,28^{\text {th days }} \\
\text { post treatment }\end{array}$ \\
\hline
\end{tabular}

Effect of $\beta$-adrenoceptor antagonist Timolol $(0.5 \% \mathrm{w} / \mathrm{v})$ treatment on dynamics of YAP, CTGF and E-Cadherin in Tear fluid

Dynamics of YAP1, CTGF and E-Cadherin before and after treatment with $\beta$ adrenergic blocker- Timolol (eye drops) was studied through immune blotting done on pooled pre treatment tear samples run against posttreatment tear samples.

\section{Statistical analysis}

The data was analyzed by using the Statistical Program for Social Sciences (SPSS 25 IBM). Independent sample ' $\mathrm{t}$ ' test and two-way ANOVA was used to compare PMF score of proteins $(0<0.05)$. The non-parametric data generated from the scoring was analyzed using MannWhitney $U$ test to compare the groups at corresponding time intervals. All the graphs were prepared in Graph Pad Prism (Version 5).

\section{RESULTS AND DISCUSSION}

\section{Animals}

Prevalence of corneal ulcer due to KCS was high $(14.35 \%)$, during this study period and has shown age wise distribution of $0-1$ year $(9,12.33 \%), 1-3$ years $(21$, $28.77 \%), 3-5$ years $(12,16.44 \%), 5-8$ years $(18,24.66 \%)$, $>8$ Years $(13,17.81 \%)$. More number of KCS cases was recorded in the age group of 1-3 years. Corneal ulcer was found more in male $(43,58.90 \%)$ than female $(30$, $41.10 \%)$ during the study. Chinese pugs $(62,89.93 \%)$ were affected more in number followed by Spitz $(3,4.11 \%)$, Mastiff (2, 2.7\%) and Boxer (2, 2.74\%). Dogs with corneal ulcer showed sluggish menace reflex, ocular discharge across eyelid margin, conjunctival hyperemia and neovascularization. Average tear production in corneal ulcer 
cases was $8.44 \pm 2.85 \mathrm{~mm} / \mathrm{min}$. Corneal ulcer is a common ocular emergency and was found associated with KCS in predisposed dog breeds like Pug (Kim et al., 2009, John et al., 2018). Reflex tear production due to corneal ulcer often masks most prominent KCS character i.e., corneal dryness (John et al., 2018). Peculiar brachycephalic conformation, reduced number of corneal nerves and subsequent loss of sensation of corneal surface was attributed to corneal ulcer in pugs (Barrett et al., 1991). Periocular features of brachycephalic dogs, such as the presence of a large palpebral aperture and a shallow socket, may additionally play interactive roles in the pathogenesis of CUD (Corneal Ulcerative Disease) (Packer et al., 2015).

\section{Wnt and YAP1 Target genes and regulators are up- regulated in tear film of corneal ulcer cases due to KCS in dogs}

Tyrosine-protein kinase Yes was found significantly $(p<0.05)$ up-regulated in corneal ulcer whereas Leukemia inhibitory factor receptor (LIFR), Angiopoietin-1 (Ang1) and Rho GTPase-activating protein 7 (DLC1) $(\mathrm{p}<0.001)$ was found significantly down regulated in corneal ulcer compared to normal tear (Fig.1.). Proteomic study revealed two prominent Src kinases in tear film of dogs; Tyrosineprotein kinase Fer and Tyrosine-protein kinase Yes; former one being more in normal tear while later was predominant in corneal ulcer. The Src family of kinases (SFK) are expressed in proliferating cells; regulate a wide variety of cellular functions such as proliferation, differentiation and survival (Abram and Courtneidge, 2000). Src kinase Yes was found to be associated with pluripotency of cells (Trouillas et al., 2009) and showed abundance in self renewing cells compared to differentiated ones (Ivanova $e t$ al., 2002). YAP1 is a powerful transcriptional co-activator, which operates many pathways that regulate proliferation and cell death, and work together downstream of Src kinase Yes along with TEAD (Tamm et al., 2011). YAP1 was discovered as binding partner of Yes (Zaidi et al., 2004). It is proved that, YAP as a substrate for Yes kinase activity; activated Yes was found associated with YAP and induced its tyrosine Phosphorylation (Tamm et al., 2011). Though Peptide signature (PMF) of YAP1 as such was not detectable in tear film of corneal ulcer cases, we assume presence of Src kinase Yes as foot print for activity of activated YAP.

Frizzled-6, G1/S-specific cyclin-D1 and Catenin beta-
1 proteins were found up-regulated in corneal ulcer tear film; several ocular tissues expressed different components of the $\mathrm{Wnt} / \beta$-catenin signaling pathway during eye development (Ang et al., 2004). Canonical Wnt signaling was proved to play a crucial role in ocular surface epithelia development wherein conditional ablation of Wnt/ $\beta$-catenin signaling in stromal keratocytes resulted in the activation of Bmp4 signaling. Role of Wnt/ $\beta$-catenin signaling in stromal mesenchyme on reciprocal mesothelial to epithelial communication and epithelial stratification of cornea is established; Wnt/ $\beta$-catenin signaling negatively correlating to corneal stratification and maturity through modulation of BMP4 expression (Zhang et al., 2015). WNT10B enhances proliferation through beta-catenin and Rac1 GTPase in human corneal endothelial cells also leading to the activation of Cyclin D1 expression and proliferation (Lee and Heur, 2015). Corneal metaplasia like changes was evident in histopathological analysis of corneal ulcer due to KCS, with loss of epithelial organization, sub epithelial fibroplasia, keratinization and pigment deposition. Neovascularization as a consequence of corneal wound healing and angiogenesis as observed clinically could be the origin of enhanced Wnt target proteins in tear film of corneal ulcer cases. Recent studies have also observed neovascularization associated with corneal healing in KCS (John et al., 2018).

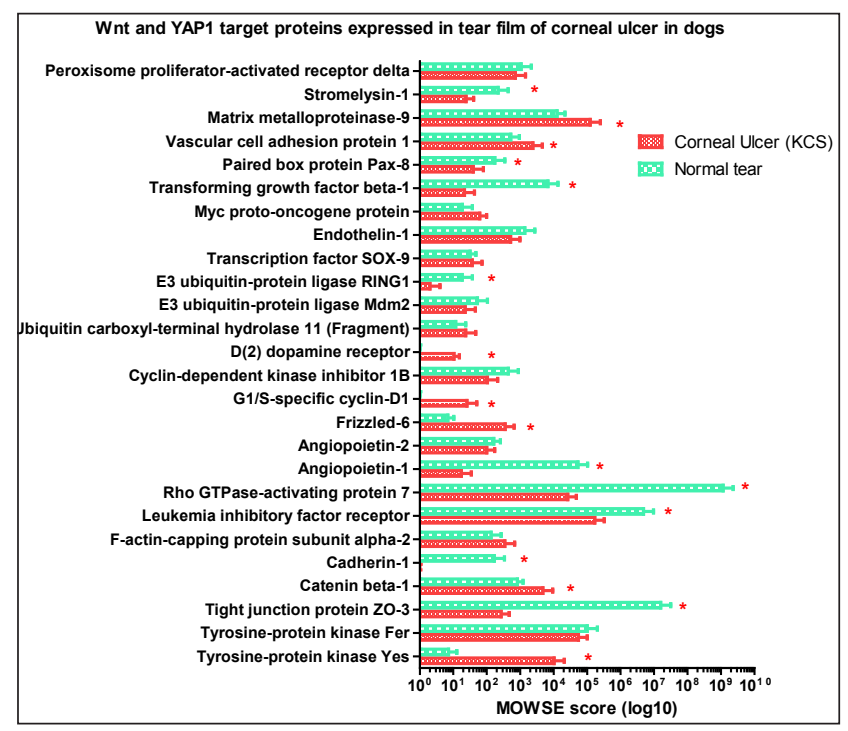

Fig. 1: Dynamics of Wnt and YAP1 target proteins and regulators expressed in tear film of corneal ulcer cases due to KCS compared to normal tear collected from healthy eyes of dogs. Significant difference is shown by asterisk mark $(p<0.05)$ 
Tight junction protein ZO-3 and Cadherin-1was found significantly down regulated in tear film of corneal ulcer. Contact inhibition to proliferation is characteristic of tissue homeostasis and differentiation which is overtaken by developmental requirements like tissue regeneration or wound healing. Expression of E-cadherin in epithelial cells and its intercellular homophilic binding leads to the formation of the epithelial junctional complex and a tight and polarized cell layer (Gumbiner et al., 1988). Most of E-cadherin dependent inhibitory mechanisms to proliferation are mediated through Src kinases and receptor tyrosine kinases (Perrais et al., 2007). Hippo pathway components were found required for E-cadherin dependent inhibition of proliferation by facilitating cell density dependent YAP sub-cellular localisation. $\beta$-catenin bound E cadherin promotes YAP Phosphorylation on $\mathrm{s} 127$ residue and prevents its nuclear localization (Kim et al., 2011).

Leukemia inhibitory factor receptor (LIFR), Rho GTPaseactivating protein 7 (DLC1) and Angiopoietin-1 (Ang1) was found significantly down regulated in corneal ulcer compared to normal tear. Rho GTPase-activating protein 7 (DLC1) was established as a regulator of YAP1; DLC1deficiency in primary endothelial cells causes the loss of cell contact inhibition of growth and was found that active/nuclear YAP was significantly more abundant in DLC1-deficient endothelial cells compared with control cells (Ritchey et al., 2019). LIFR triggers a kinase cascade that leads to phosphorylation, cytoplasmic retention and functional inactivation of YAP and inhibits cancer metastasis through phosphorylation-dependent inactivation of YAP and its target CTGF (Chen et al., 2012). Ang1 helps to promote and maintain quiescence and integrity of the endothelium in mature vessels and its expression is essential for vessel survival, inhibition of vascular leakage and suppression of inflammatory gene expression, while Ang2 suppresses the effects of Ang1 resulting in vessel destabilization (Brindle et al., 2006). Ang-2 is relatively highly expressed at the active sites of vascular remodelling and plays a key role in controlling endothelial remodelling and angiogenesis (Augustin et al., 2009). Endothelial cells are the primary source of ANG2; cytokines or hypoxia can transcriptionally regulate its production (Mandriota and Pepper, 1998). YAP was found to regulate endothelial expression of ANG-2 by modulating Ang-1 which is important in vascular remodelling and angiogenesis in endothelial cells (Choi et al., 2015).

\section{Increased YAP1, CTGF and E-cadherin in tear film of corneal ulcer due to KCS in dogs}

Intensity of expression of YAP during western blotting was found more in corneal ulcer tear than normal tear. Expression of CTGF was faintly appreciated in normal tear, but, CTGF expression was more in corneal ulcer tear. Intensity of expression of E-Cadherin was almost similar in both normal and ulcer tear (Fig. 2.A)

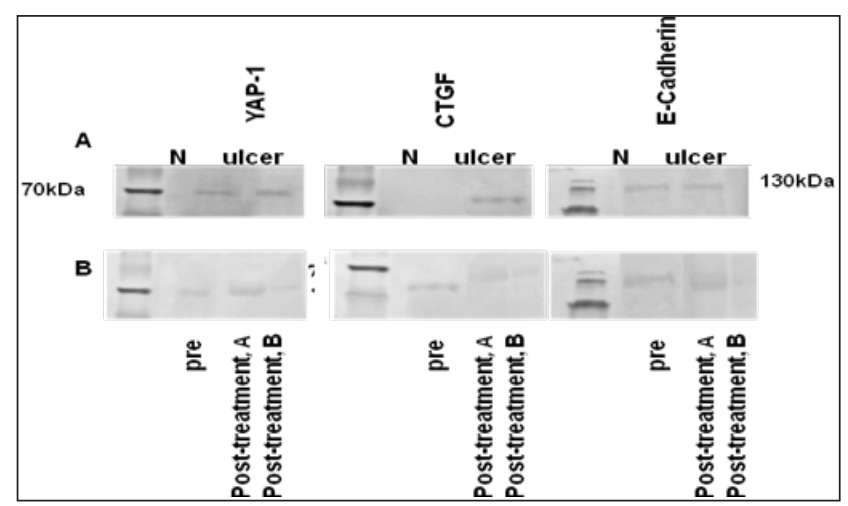

Fig. 2: Western blot showing protein expression of YAP1, CTGF and E-Cadherin in tear film of dogs suffering from corneal ulcer due to KCS (ulcer) and normal tear (N) (A) Expression of YAP1, $\mathrm{CTGF}$ and E-Cadherin in tear film before and after treatment with $\beta$ adrenoceptor antagonist Timolol $(0.5 \%)$ ophthalmic drops, pooled pre-treatment tear (pre), post treatment tear in group A and in group B is depicted (B)

\section{Corneal tissue expression of YAP and its downstream targets CTGF and E-Cadherin was found enhanced in KCS}

Corneal tissue collected for histopathology and in situ detection of proteins revealed hyperplasia of anterior corneal epithelium (stratified squamous epithelium) characterized by increased epithelial layers and epithelial hyperkeratosis in KCS cornea (Fig.3.B) compared to normal corneal epithelium. Normal cornea did not show keratinization of superficial epithelium, was closely adhered to avascular stroma and did not show pigmentation. (Fig.3A). Hyperplasia of corneal epithelium can be a regenerative response to injury; through permanent inflammatory response as in KCS can cause dysplastic changes and fibrosis. Lack of epithelial 
organization, sub-epithelial fibroplasia (Fig. 3C) and blood vessels appearing on cornea were suggestive of corneal metaplasia. Detachment of anterior epithelium from under lying stroma was evident, probably due to loss of hydrophobic epithelial barrier or oedema. Infiltration of Mononuclear cells in stromal substance was evident. Rete ridges, adaptive keratinization and pigmentation were found in cornea with KCS (Fig. 3.D).

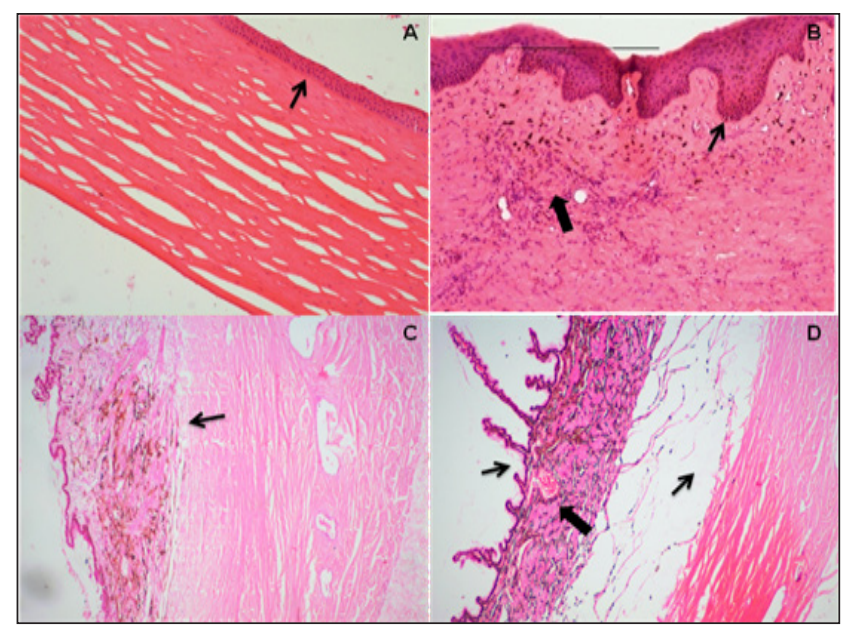

Fig. 3: Histopathology of corneal tissue from normal dog showing non keratinized epithelium in close contact with underlying stroma $(\uparrow)$ and intact endothelium (A), compared to tissue from healing ulcer in a KCS afflicted pug showing hyperplasia of anterior epithelium $(\uparrow)$, sub epithelial fibroplasia and mononuclear cell infiltration of corneal stroma (bold arrow) (B) Loss of epithelial cell layers and fibrosis $(\uparrow)(C)$, rete ridges $(\uparrow)$, neovascularization (bold arrow), detachment of anterior epithelium from stroma $(\uparrow)$ is also evident in healing corneal ulcer due to KCS (D)

Mild YAP1 immune reactivity was observed in normal corneal tissue near stromal keratinocytes (Fig. 5, 4B) whereas moderate to high immune reactivity of YAP was found in the basal, hyper proliferated epithelial cells of KCS affected cornea (Fig. 4C, D). Similarly, high immune reactivity of CTGF was found in the nuclear region of disorganized hyper-proliferative corneal epithelium (Fig. 5.C\&D) compared meagre ((Fig. 5.A) and mild CTGF immune reactivity in normal corneal stroma (Fig. 5B). E-cadherin immune reactivity was mild in the epithelium of both normal cornea and cornea with KCS (Fig. 6A, B, $\& C)$ whereas moderate immune reactivity was found in stroma of cornea with KCS (Fig. 6D). Inflammatory cells in stroma were characteristic of histopathology of corneal ulcer; a dense inflammatory cell infiltrate was demonstrated in the superficial stroma in chronic superficial keratitis in dogs (Williams, 1999). Corneal ulcer tissue from KCS affected dogs showed intense immune-reactivity for YAP in basal epithelial layer of stratified squamous epithelium as well as in proliferated fibroblasts of corneal stroma; basal epithelial and limbal cell immune-reactivity to YAP was reported earlier (Kasetti et al., 2016). Immunoreactivity of CTGF protein was abundant in the nucleus of epithelial layer of ulcerated cornea. CTGF is a downstream target of YAP signaling (Dupont et al., 2011) a target of TEAD transcription and a critical cytokine in corneal wound healing (Van Setten et al., 2016). Intensity of expression of YAP1 was more in corneal ulcer tear sample than normal tear on immune-blotting. Expression of CTGF was faintly appreciated in normal tear, But, CTGF expression was more in corneal ulcer tear. Intensity of expression of E-cadherin was similar in both normal and corneal ulcer tear. Results of immune-blotting of tear film corroborated with the results of IHC in corneal tissue.

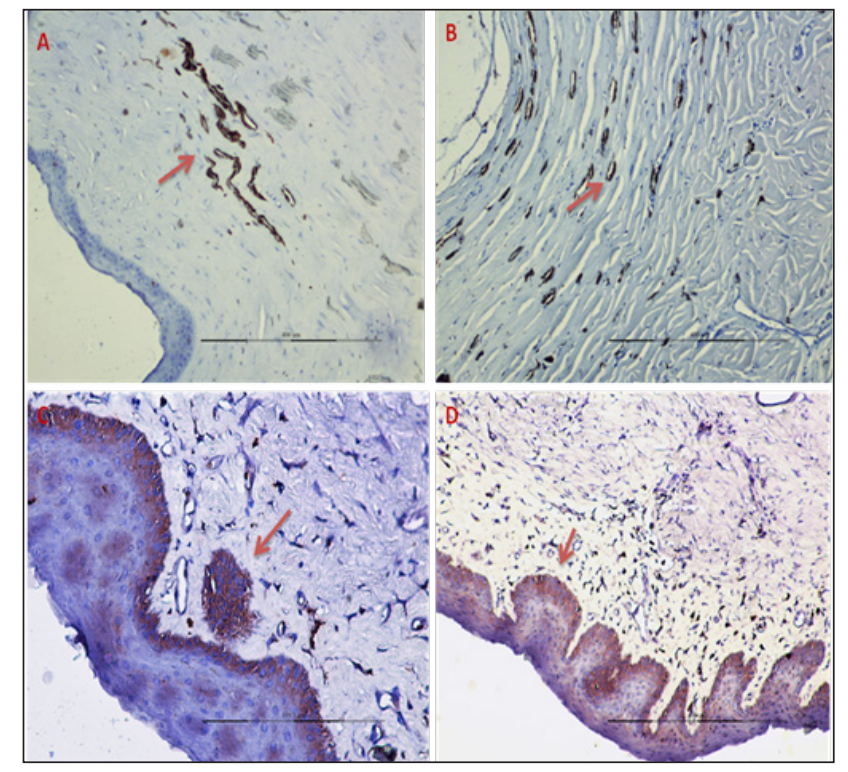

Fig. 4: Formalin fixed paraffin embedded tissue sections of normal cornea showed mild immune reactivity for YAP1 at the connective tissue stroma, especially at stromal keratinocytes level $(\uparrow)$ IHC, X100 (A) IHC, X200 (B) where as pug cornea affected with corneal ulcer due to KCS showing intense immune-reactivity for YAP1 in basal epithelial layer of stratified squamous epithelium $(\uparrow)$ as well as fibroblast proliferation $(\uparrow)$ in stroma of cornea (C) and intense immune localisation of YAP in basal epithelial cells of cornea (D) 


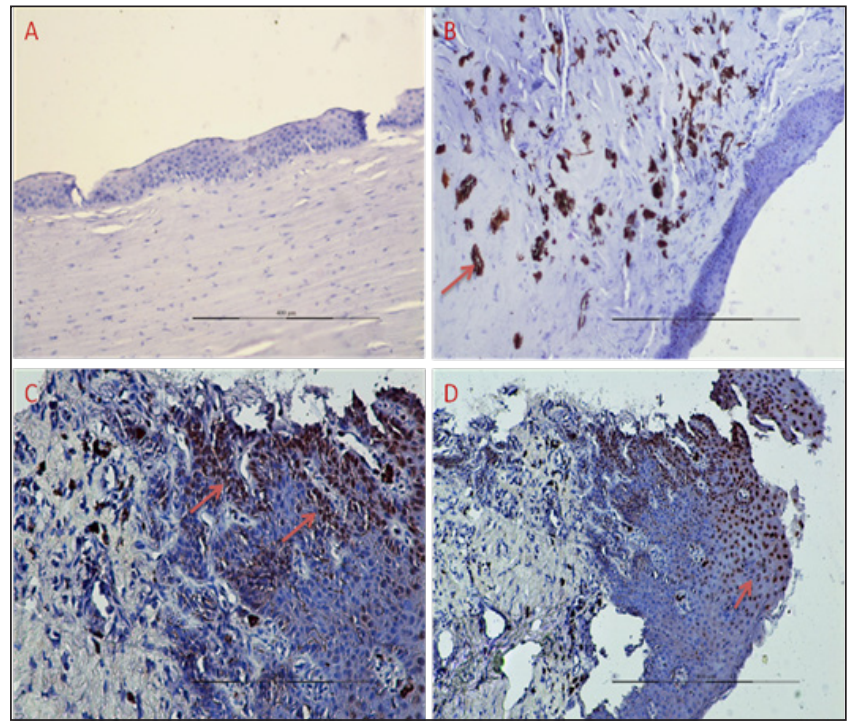

Fig. 5: Formalin fixed paraffin embedded tissue sections of normal cornea no signals of CTGF in epithelial layer (A) but showing mild immune localization of CTGF in stromal layer of cornea ( $\uparrow$ ) (IHC, X100), (B) corneal tissue with KCS related corneal ulcer tissue showing strong immune localization of CTGF protein in melanin rich affected epithelial layer of cornea $(\uparrow)$ as indicated by strong brown colour signals ( $\uparrow$ ) (IHC, X 100) (C) and intense immune localization of CTGF in nucleus of anterior epithelium in cornea (D)

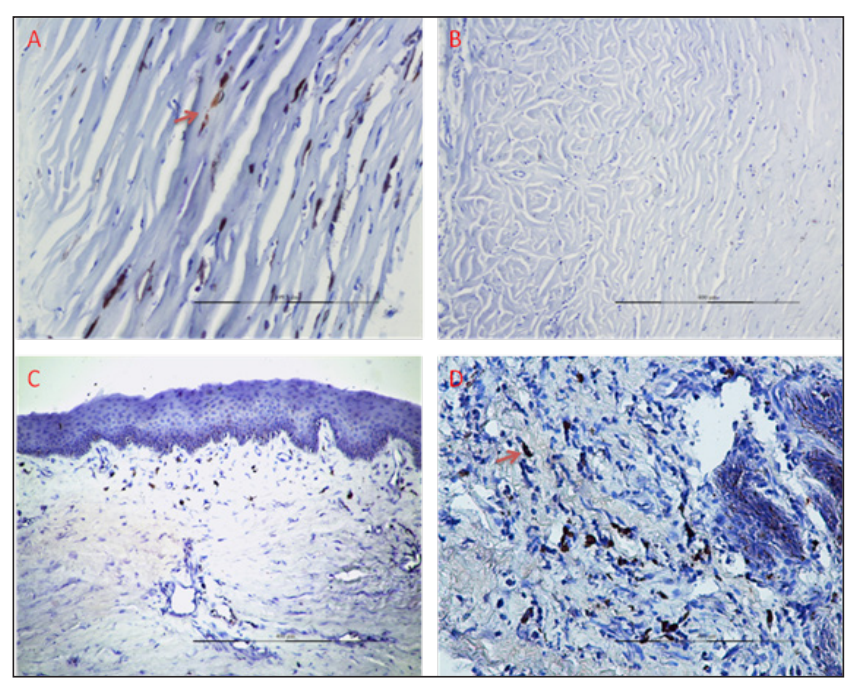

Fig. 6: Mild E-Cadherin immune-reactivity appreciated in normal corneal stroma ( $\uparrow$ ) (IHC, X200) (A) whereas no immunelocalization of E-Cadherin was appreciated in corneal epithelial layer of normal cornea (IHC, X100) (B) Corneal ulcer (KCS) tissue showed mild immune reactivity for E-cadherin at the basal layer of stratified superficial cornea ( $\uparrow$ ) (C) and moderate reactivity in connective tissue stroma $(\uparrow)(\mathrm{D})$ $\beta$ adrenoceptor antagonist Timolol $(0.05 \%$ w/v) drops improved corneal wound healing meanwhile enhanced progression of corneal pigmentation in corneal ulcer due to $\mathrm{KCS}$

Demographic and clinical observation of cornel ulcer cases in groups A and B is depicted in table 2 and 3, respectively. Clinically, menace response was abolished in both groups on the day of presentation. Menace response was improved in both groups (Fig. 7. A) which was significant in group $B(p<0.05)$ post treatment. Increased ocular discharge over the cornea and across the eyelid margins on the day of presentation and on $7^{\text {th }}$ day of post treatment was seen in both groups which subsequently and significantly decreased from $14^{\text {th }}$ to $28^{\text {th }}$ day of post treatment in both the groups (Fig. 7. B). Similar trend was seen for conjunctival hyperemia also in both groups posttreatment (Fig. 7.C). Tear production was more in group A at pre treatment period, which was increased on $7^{\text {th }}$ day and $28^{\text {th }}$ day post treatment intervals. In group $\mathrm{B}$, tear production gradually increased from the day of presentation to $28^{\text {th }}$ day of post treatment (Fig. 7. D). Fluorescein stain retention in the cornea was significantly high in group B. FDT scores improved further significantly $(p<0.05)$ in group B post treatment (Fig. 7. E). Corneal ulcer healing was also significant in both groups post treatment (Fig. 7. F). Cornea was opaque on the day of presentation in group B and clarity gradually incerased $(p<0.05)$ and cornea was clear on $28^{\text {th }}$ day of post treatment. Corneal clarity scores were significantly $(\mathrm{p}<0.05)$ high in group A on pretreatment day compared to B (Fig. 7. G). There was an appreciable difference in corneal pigmentation density on the day of presentation between groups (Fig. 7. I). Gradual increase in corneal pigmentation was observed in group B which was found significant $(\mathrm{p}<0.05)$ at $28^{\text {th }}$ day compared to group A (Fig. 8. H). Photographic evaluation of corneal ulcer healing in both groups is depicted in Fig. $8(\mathrm{a}, \mathrm{b})$.

Beta adrenoreceptor antagonism has been proved to accelerate corneal wound healing (Ghoghawala et al., 2008). Clinically and photographically, Timolol (0.5\%) improved corneal wound healing but also increased corneal pigmentation and its density compared to nontimolol treated group. Tear film immunoblotting post treatment showed a decreased intensity of YAP, CTGF and E-Cadherin (Fig. 2.B) which we assume, could be due to nuclear translocation of these proteins and their activation 
Table 2: Demographic data of clinical cases of corneal ulcer cases included in study

\begin{tabular}{lllllll}
\hline Animal no. & Breed & Age & Gender & OD/OS & Primary lesion & Concurrent anomaly \\
\hline A-1 & Pug & $31 / 2$ years & Female & OD & Moderate & Pigmentary keratitis \\
A-2 & Pug & $3 \frac{1}{2}$ years & Female & OS & Moderate & Pigmentary keratitis \\
A-3 & Pug & $1 \frac{1}{2}$ years & Male & OD & Deep & Pigmentary keratitis \\
A-4 & Pug & 2 years & Male & OD & Deep & Pigmentary keratitis \\
A-5 & Pug & $1 \frac{1}{2}$ years & Male & OD & Descemetocele & - \\
A-6 & Pug & $1 \frac{1}{2}$ years & Male & OD & Superficial ulcer & Pigmentary keratitis \\
B-1 & Pug & 2 years & Male & OS & Descemetocele & Pigmentary keratitis \\
B-2 & Pug & 10 months & Female & OD & Descemetocele & Pigmentary keratitis \\
B-3 & Pug & 2 years & Female & OD & Deep & Pigmentary keratitis \\
B-4 & Pug & $8 \frac{1}{2}$ years & Female & OS & Descemetocele & Pigmentary keratitis \\
B-5 & Pug & $1 \frac{1}{2}$ years & Male & OD & Descemetocele & Pigmentary keratitis \\
B-6 & Pug & 2 years & Male & OS & Descemetocele & Pigmentary keratitis \\
\hline
\end{tabular}

Table 3: Clinical evaluation by scoring different parameters observed at the time of presentation of corneal ulcer cases suffering from KCS

\begin{tabular}{|c|c|c|c|c|c|c|c|c|c|}
\hline $\begin{array}{l}\text { Anim. } \\
\text { no. }\end{array}$ & OD/OS & $\begin{array}{l}\text { Menace } \\
\text { reflex }\end{array}$ & $\begin{array}{l}\text { Ocular } \\
\text { discharge }\end{array}$ & $\begin{array}{l}\text { Transparency } \\
\text { of cornea }\end{array}$ & $\begin{array}{l}\text { Conjunctival } \\
\text { hyperemia }\end{array}$ & $\begin{array}{l}\text { Corneal } \\
\text { neovascularization }\end{array}$ & $\begin{array}{l}\text { Corneal } \\
\text { pigmentation }\end{array}$ & $\begin{array}{l}\text { STT } \\
(\mathrm{mm} / \mathrm{min})\end{array}$ & FDT \\
\hline A-1 & OS & Absent & $\begin{array}{l}\text { Discharge } \\
\text { across cornea }\end{array}$ & $\begin{array}{l}\text { Complete } \\
\text { opacity }\end{array}$ & Severe & $\begin{array}{l}\text { Limbal corneal } \\
\text { vessel }\end{array}$ & $\begin{array}{l}\text { Pigment less } \\
\text { than } 25 \% \\
\text { cornea }\end{array}$ & 18 & $<50 \%$ \\
\hline A-2 & OD & Sluggish & No discharge & $\begin{array}{l}\text { Complete } \\
\text { opacity }\end{array}$ & Mild & No corneal vessel & $\begin{array}{l}\text { No } \\
\text { pigmentation }\end{array}$ & 11 & $<50 \%$ \\
\hline A-3 & OD & Absent & No discharge & $\begin{array}{l}\text { Moderate } \\
\text { opacity }\end{array}$ & Mild & No corneal vessel & $\begin{array}{l}\text { No } \\
\text { pigmentation }\end{array}$ & 11 & $<50 \%$ \\
\hline A-4 & OD & Absent & $\begin{array}{l}\text { Slight } \\
\text { discharge }\end{array}$ & $\begin{array}{l}\text { Complete } \\
\text { opacity }\end{array}$ & Mild & No corneal vessel & $\begin{array}{l}\text { No } \\
\text { pigmentation }\end{array}$ & 18 & $<50 \%$ \\
\hline A-5 & OD & Absent & $\begin{array}{l}\text { Discharge } \\
\text { across cornea }\end{array}$ & $\begin{array}{l}\text { Moderate } \\
\text { opacity }\end{array}$ & Absent & No corneal vessel & $\begin{array}{l}\text { No } \\
\text { pigmentation }\end{array}$ & 0 & $<50 \%$ \\
\hline A-6 & OD & Sluggish & $\begin{array}{l}\text { Discharge } \\
\text { across cornea }\end{array}$ & $\begin{array}{l}\text { Moderate } \\
\text { opacity }\end{array}$ & Severe & No corneal vessel & $\begin{array}{l}\text { No } \\
\text { pigmentation }\end{array}$ & 6 & $50-75 \%$ \\
\hline B-1 & OS & Sluggish & $\begin{array}{l}\text { Slight } \\
\text { discharge }\end{array}$ & $\begin{array}{l}\text { Moderate } \\
\text { opacity }\end{array}$ & Mild & $\begin{array}{l}\text { Vessels halfway } \\
\text { towards the corneal } \\
\text { axis }\end{array}$ & $\begin{array}{l}\text { Pigment over } \\
25-50 \% \text { cornea }\end{array}$ & 9 & $50-75 \%$ \\
\hline B-2 & OD & Sluggish & $\begin{array}{l}\text { Slight } \\
\text { discharge }\end{array}$ & $\begin{array}{l}\text { Moderate } \\
\text { opacity }\end{array}$ & Mild & $\begin{array}{l}\text { Vessels halfway } \\
\text { towards the corneal } \\
\text { axis }\end{array}$ & $\begin{array}{l}\text { No } \\
\text { pigmentation }\end{array}$ & 6 & $50-75 \%$ \\
\hline B-3 & OD & Absent & $\begin{array}{l}\text { Discharge } \\
\text { across cornea }\end{array}$ & $\begin{array}{l}\text { Complete } \\
\text { opacity }\end{array}$ & Severe & $\begin{array}{l}\text { Vessels halfway } \\
\text { towards the corneal } \\
\text { axis }\end{array}$ & $\begin{array}{l}\text { No } \\
\text { pigmentation }\end{array}$ & 17 & $>75 \%$ \\
\hline B-4 & OS & Absent & $\begin{array}{l}\text { Discharge } \\
\text { across cornea }\end{array}$ & $\begin{array}{l}\text { Complete } \\
\text { opacity }\end{array}$ & Absent & No corneal vessel & $\begin{array}{l}\text { No } \\
\text { pigmentation }\end{array}$ & 1 & $50-75 \%$ \\
\hline B-5 & OS & Sluggish & $\begin{array}{l}\text { Slight } \\
\text { discharge }\end{array}$ & $\begin{array}{l}\text { Complete } \\
\text { opacity }\end{array}$ & Mild & No corneal vessel & $\begin{array}{l}\text { No } \\
\text { pigmentation }\end{array}$ & 10 & $>75 \%$ \\
\hline B-6 & OS & Absent & $\begin{array}{l}\text { Slight } \\
\text { discharge }\end{array}$ & $\begin{array}{l}\text { Complete } \\
\text { opacity }\end{array}$ & Mild & $\begin{array}{l}\text { Vessels extending to } \\
\text { axial cornea }\end{array}$ & $\begin{array}{l}\text { No } \\
\text { pigmentation }\end{array}$ & 13 & $>75 \%$ \\
\hline
\end{tabular}




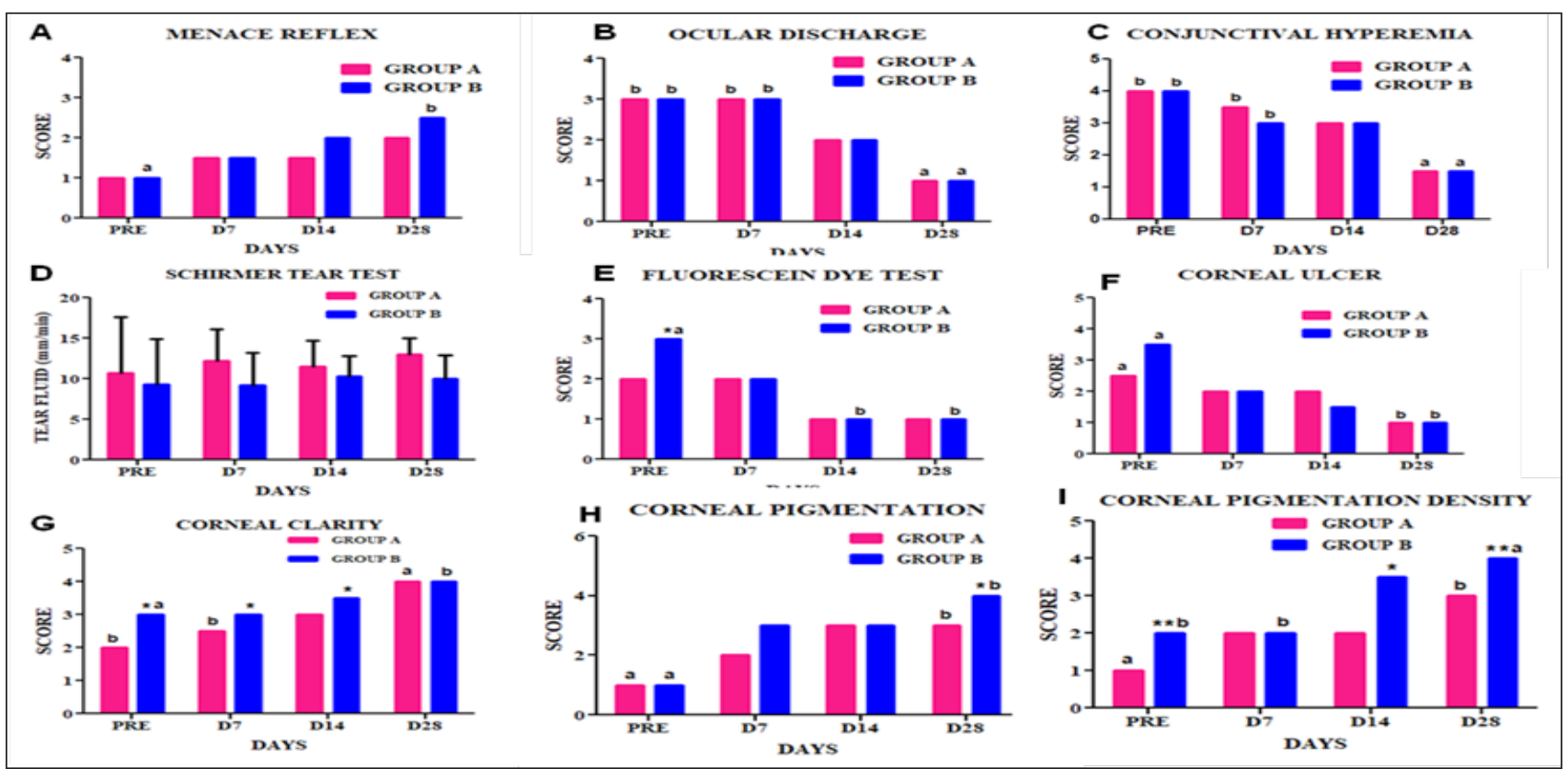

Fig. 7: Clinical evaluation of corneal wound healing in dogs suffering from KCS (group A and group B); Menace reflex showed significant improvement post treatment in group B (D28) (A); Ocular discharge (B) and conjunctival hyperaemia (C) significantly reduced in both treatment groups; Improvement in tear production post treatment as seen by Schirmer Tear test; Fluorescent dye uptake and corneal ulcer significantly reduced post treatment $(\mathbf{E}, \mathbf{F})$; Corneal clarity improved significantly in both groups post treatment $(\mathbf{G})$ : corneal pigmentation area and corneal pigmentation density was found significantly enhanced in group B compared to group A $(\mathbf{H}, \mathbf{I})$ : significant different between groups is depicted as asterisk mark $*(p<0.05), * *(p<0.001)$, significant difference between treatment intervals is depicted as superscripts $(a, b)$

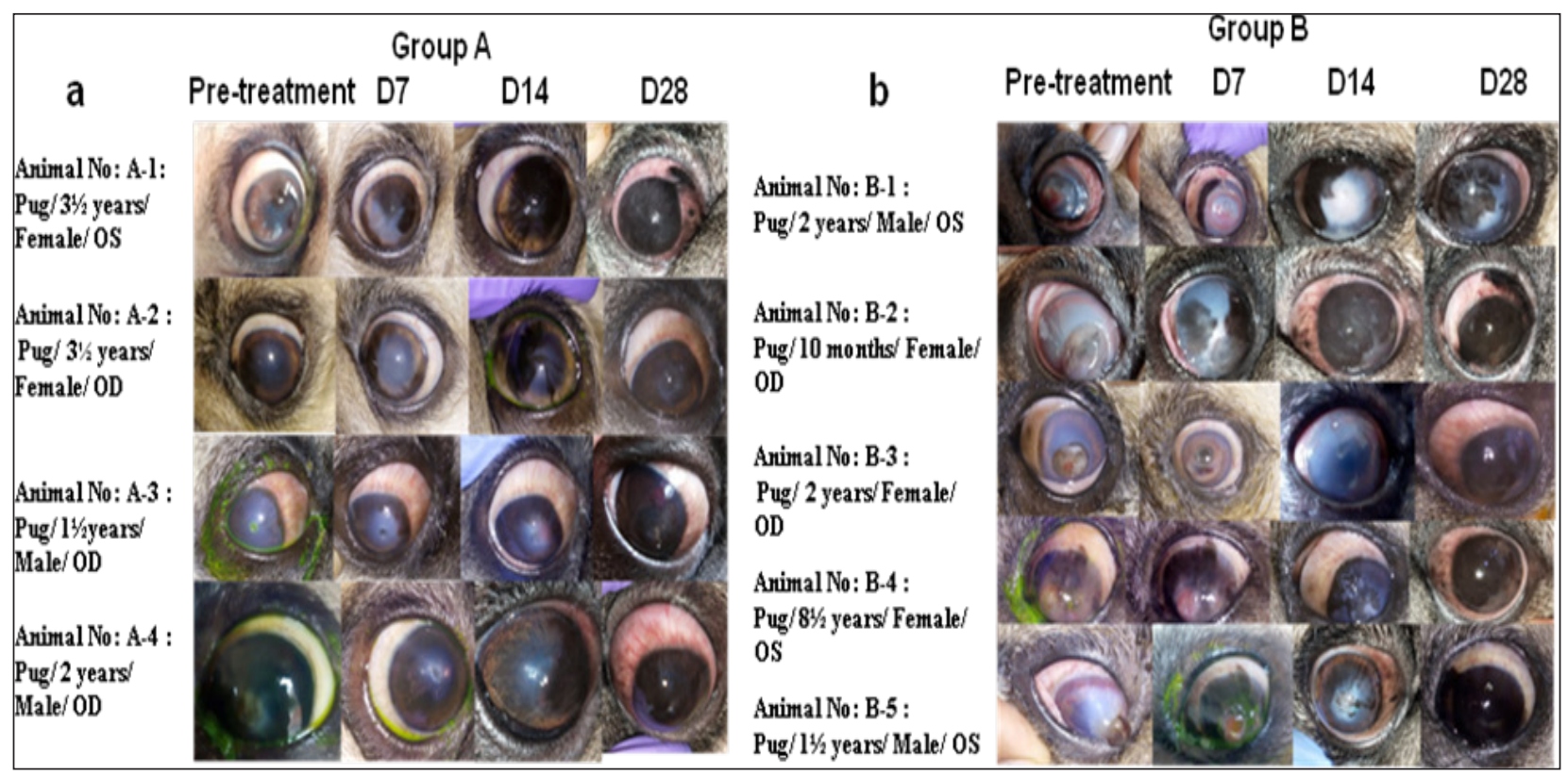

Fig. 8: Photographic evaluation of corneal ulcer healing in group A before and after conventional treatment on D7, D14 and D 28 (a) and in group B before and after Timolol treatment ( $0.5 \%$ drops topically) on D7, D14 and D 28 (b) 
and lesser cytosolic accumulation. It is also presumed that corneal pigmentation irreversibly reduces corneal clarity and pigmentation proceeds over the fibrosed cornea, hence despite the advantage of enhanced healing, beta adrenoceptor blocking activates YAP signaling and augments corneal pathology of KCS affected cornea in dogs.

\section{CONCLUSION}

Tear fluid in corneal ulcer due to KCS revealed significant up-regulation of many Wnt and YAP activators and target proteins in dogs, which were suggestive of cell proliferation and vascular endothelial cell activation due to neovascularization. YAP1 activity, as observed on the basal epithelial layer, was associated with corneal pathology in KCS cases. Deficiency of DCL1, LIFR and Ang-1 also might contribute to up-regulation of Src family kinase YES1 and YAP1 activation. Beta adrenoceptor blocking enhanced cell proliferation and thus was helpful in corneal wound healing but augmented KCS pathology in corneal tissue. Identification of key players in KCS pathology through tear fluid proteomic study will help to chalk out better therapeutic strategies to address corneal pathology in due to KCS in susceptible dog breeds.

\section{ACKNOWLEDGEMENTS}

Authors gratefully acknowledge research fund provided by DBT and ICAR-IVRI.

\section{REFERENCES}

Abram, C.L. and Courtneidge, S.A. 2000. Src family tyrosine kinases and growth factor signaling. Exp. Cell. Res., 254: $1-13$.

Ang, S.J., Stump, R.J.W., Lovicu, F.J. and McAvoy, J.W. 2004. Spatial and temporal expression of Wnt and Dickkopf genes during murine lens development. Gene. Expr. Patterns., 4: 289-295.

Argüeso, P., Balaram, M., Spurr-Michaud, S., Keutmann, H.T., Dana, M.R. and Gipson, I.K. 2002. Decreased levels of the goblet cell mucin MUC5AC in tears of patients with Sjogren syndrome. Invest. Ophthalmol. Vis. Sci., 43: 1004-1011.

Augustin, H.G., Koh, G.Y., Thurston, G. and Alitalo, K. 2009. Control of vascular morphogenesis and homeostasis through the angiopoietin-Tie system. Nat. Rev. Mol. Cell. Biol., 10: 165-177.
Bao Y., Nakagawa K., Yang Z., Ikeda, M., Withanage, K., Ishigami-Yuasa, M., Okuno Y., Hata, S., Nishina, H. and Hata, Y. 2011. A cell-based assay to screen stimulators of the Hippo pathway reveals the inhibitory effect of dobutamine on the YAP-dependent gene transcription. J. Biochem., 150: 199-208.

Barrett, P.M., Scagliotti, R.H., Merideth, R.E., Jackson, P.A. and Alarcon, F.L. 1991. Absolute corneal sensitivity and corneal trigeminal nerve anatomy in normal dogs. Prog. Vet. Comp. Ophthalmol., 1: 245-254.

Brindle, N.P., Saharinen, P. and Alitalo, K. 2006. Signaling and functions of angiopoietin-1 in vascular protection. Circ. Res., 98:1014-1023.

Chen, D., Sun, Y., Wei, Y., Zhang, P., Rezaeian, A.H., TeruyaFeldstein, J., Gupta, S., Liang, H., Lin, H.K., Hung, M.C. and Ma, L. 2012. LIFR is a breast cancer metastasis suppressor upstream of the Hippo-YAP pathway and a prognostic marker. Nat Med., 18: 1511-1517.

Choi, H., Zhang, H., Park, H., Choi, K.S., Lee, H.W., Agrawal,V., Kim, Y.M. and Kwon, Y.G. 2015. Yes-associated protein regulates endothelial cell contact-mediated expression of angiopoietin-2. Nat. Commun., 6: 6943.

Corr, A. 2015. Canine dry eye: Canine keratoconjunctivitis sicca (KCS). Met. Vet. Assoc., 4: 1-4.

Dupont, S., Morsut, L., Aragona, M., Enzo, E., Giulitti, S., Cordenonsi, M., Zanconato, F.,rancesca , Digabel, J., Forcato, M., Bicciato, S., Elvassore, N. and Piccolo, S. 2011. Role of YAP/TAZ in mechanotransduction. Nature, 474: 179-183.

Ghoghawala S.Y., Mannis M.J., Pullar C.E., Rosenblatt, M.I. and Isseroff, R.R. 2008. 32 -Adrenergic receptor signaling mediates corneal epithelial wound repair. Invest. Ophthalmol. Vis. Sci., 49: 1857-1863.

Gumbiner, B., Stevenson, B. and Grimaldi, A. 1988. The role of the cell adhesion molecule uvomorulin in the formation and maintenance of the epithelial junctional complex. $J$. Cell Biol., 107: 1575-1587.

Hendrix D.V., Adkins E.A., Ward D.A., Stuffle, J. and Skorobohach, B. 2011. An investigation comparing the efficacy of topical ocular application of tacrolimus and cyclosporine in dogs. Vet. Med. Int., 2011:487592.

Ivanova, N.B., Dimos, J.T., Schaniel, C., Hackney, J.A., Moore, K. A. and Lemischka, I.R. 2002. A stem cell molecular signature. Science, 298: 601-604.

John C., Gopinathan A., Singh, K., Sharma, P., Sowbharenya, C. and Sarangom, S.B. 2018. Clinical evaluation of topical tacrolimus ointment usage in different stages of keratoconjunctivitis sicca in dogs. Turk. J. Vet. Anim. Sci., 42: 259-268. 
John, C., Gopinathan, A., Singh, K., Sowbharenya, C., Kumar, N., Sahoo, M. and Agrawal, R.K. 2020. Conjunctival Immunocytochemistry with Interferon Gamma and Caspase 3 for Clinical Staging of Keratoconjunctivitis Sicca (KCS) in Dogs. Int. J. Curr. Microbiol. App. Sci. 9: 2952-2961.

Kasetti, R.B., Gaddipati, S., Tian, S., Xue, L., Kao, W.W.-Y., Lu, Q. and Li, Q. 2016. Study of corneal epithelial progenitor origin and the Yap1 requirement using keratin 12 lineage tracing transgenic mice. Sci. Rep., 6: 35202.

Kim, J.Y. and Won, H.J. 2009. Jeong Soon-wuk. A Retrospective Study of Ulcerative Keratitis in 32 Dogs, Intern. J. Appl. Res. Vet. Med., 7: 27-31.

Kim, N.G.1., Koh, E., Chen, X. and Gumbiner, B.M. 2011. E-cadherin mediates contact inhibition of proliferation through Hippo signaling-pathway components. Proc. Natl. Acad. Sci. (U S A), 108: 11930-11935.

Konsavage, W.M. Jr. and Yochum, G.S. 2013. Intersection of Hippo/YAP and $\mathrm{Wnt} / \beta$-catenin signaling pathways. Acta Biochim. Biophys.Sin. (Shanghai), 45:71-79.

Lee, J.G. and Heur, M. 2015. WNT10B Enhances Proliferation through b-Catenin and RAC1 GTPase in Human Corneal Endothelial Cells. J. Biol. Chem., 290: 26752-26764.

Mandriota, S.J. and Pepper, M.S. 1998. Regulation of angiopoietin-2 mRNA levels in bovine microvascular endothelial cells by cytokines and hypoxia. Circ. Res., 83: 852-859.

Miller, W.W. 2001. Evaluation and management of corneal ulcerations: a systematic approach. Clin. Tech. Small Anim. Pract., 16: 51-57.

Packer, R.M., Hendricks, A. and Burn, C.C. 2015. Impact of facial conformation on canine health: corneal ulceration. PLoS One, 10: e0123827.

Perrais, M., Chen, X., Perez-Moreno, M. and Gumbiner, B.M. 2007. E-cadherin homophilic ligation inhibits cell growth and epidermal growth factor receptor signaling independently of other cell interactions. Mol. Biol. Cell., 18: 2013-2025.

Posa, A., Bräuer, L., Schicht, M., Garreis, F., Beileke, S. and Paulsen, F. 2013. Schirmer strip vs. capillary tube method: non-invasive methods of obtaining proteins from tear fluid. Ann. Anat., 195: 137-142.

Reidy, J.J., Zarzour, J., Thompson, H.W. and Beuerman, R. W. 1994. Effect of topical beta blockers on corneal epithelial wound healing in the rabbit. Br. J. Ophthalmol., 78: 377-380.

Ritchey, L., Taekyu H., Atsushi O., Kabashima, K., Wang,D., Wang,Y., Lowy, D.R. and Tosato, G. 2019. DLC1 deficiency and YAP signaling drive endothelial cell contact inhibition of growth and tumorigenesis. Oncogene., 38: 7046-7059.

Sansom, J. and Barnett, K.C. 1985. Keratoconjunctivitis sicca in the dog: a review of two hundred cases. J. Small Anim. Pract., 26: 121-131.
Sarangom, S.B., Venugopal, S.K., Martin, K.J., Narayanan, M. K., Mini, M. and Anoop, S. 2014. Incidence and predisposing factors of keratopathies in Chinese Pugs. Indian Vet. J., 91: 41-43.

Soria, J., Acera, A., Merayo-LLoves, J. 2017. Tear proteome analysis in ocular surface diseases using label-free LC-MS/ $\mathrm{MS}$ and multiplexed-microarray biomarker validation. Sci. Rep., 7: 17478.

Swapana, C.R., Gopinathan, A., Singh, K., Sasikala, R., Kumar, A., Chelladuraai, S., Kumar, N., Sahoo, M. and Agrawal, R.K. 2020. Down-regulation of rho GTPase-activating protein 7 (DLC1) in tear film and modulation of rho GTPase dynamics by Rosuvastatin in dogs suffering from keratoconjunctivitis sicca. J. Anim. Res., 10(6): 889-898.

Tamm, C., Böwer, N. and Annerén, C. 2011. Regulation of mouse embryonic stem cell self-renewal by a Yes-YAPTEAD2 signaling pathway downstream of LIF. J. Cell Sci., 124: 1136-1144.

Trouillas, M., Saucourt, C., Guillotin, B., Gauthereau, X., Ding, J., Buchholz, F., Doss, M. X., Sachinidis, A., Hescheler, J., Hummel, O., Huebner, N., Kolde, R., Vilo, J., Schulz,H. and Bœuf, H. 2009. Three LIF dependent signatures and gene clusters with atypical expression profiles, identified by transcriptome studies in mouse ES cells and early derivatives. BMC Genomics, 10: 73.

Van Setten, G.B., Trost, A., Schrödl, F., Kaser-Eichberger, A., Bogner, B., Setten, M.V., Heindl, L.M., Grabner, G. and Reitsamer, H. A. 2016. Immunohistochemical detection of CTGF in the human eye. Curr. Eye. Res., 41: 1571-1579.

Webster J, Oxley D. 2012. Protein identification by MALDITOF mass spectrometry. Methods Mol. Biol., 800: 227-40.

Williams, D.L. 1999. Histological and immunohistochemical evaluation of canine chronic superficial keratitis. Res. Vet. Sci., 67:191-195.

Williams, D.L. and Tighe, A.A. 2018. Immunohistochemical evaluation of lymphocyte populations in the nictitans glands of normal dogs and dogs with keratoconjunctivitis sicca. Open Vet. J., 8: 47-52.

Zaidi, S.K., Sullivan, A.J., Medina, R., Ito,Y., Wijnen, A.J.V., Stein, J.L., Lian, J.B. and Stein, G.S. 2004. Tyrosine phosphorylation controls Runx2-mediated subnuclear targeting of YAP to repress transcription. EMBO J., 23: 790799.

Zhang, Y., Yeh, L.K., Zhang, S., Call,M., Yuan, Y., Yasunaga, M., Kao, W.W.-Y. and Liuet, C.Y. 2015. Wnt/ $\beta$-catenin signaling modulates corneal epithelium stratification via inhibition of Bmp4 during mouse development. Development, 142: 3383-3393. 